\title{
IMPLICATIONS OF POLITICAL PARTY RECALL RIGHTS TOWARD DPRD MEMBERSHIP
}

\author{
Aulia Rahman, Sudarsono, Tunggul Anshari \\ Master of Law, Postgraduate Program, University of Brawijaya \\ Jl. MT. Haryono No 169 Malang, East Java, Indonesia \\ E-mail: rhmanaulia@gmail.com
}

\begin{abstract}
The concept of recall hegemony to DPRD members to their roles as people's representatives who are representatives of political parties and constituents, can influence the work and performance of DPRD members. Recall rights by political parties can limit the political rights of council members, while shifting people's sovereignty to the sovereignty of political parties. recall procedures for members of the DPRD either through direct political parties or public complaints to the Council's Honorary Board remain through the mechanism of political party decisions. However, there is no legal legitimacy for DPRD members to make legal remedies against recall and guarantee of return of rights if it is proven that it does not fulfill the reason for recall.
\end{abstract}

Keywords: Recall Rights; Political Parties; DPRD Membership

\section{A. INTRODUCTION}

Recall is the right that a political party has to withdraw the elected members by giving a list of proposed candidates. ${ }^{1}$ In the concept of recall of MPs who have been elected as part of the rights of political parties, the author disagrees with the concept because it gives the role of political parties that can affect the area of performance of the MP, which in this mind the author feels that the recall of the MP became the sovereignty of the party, not the sovereignty of the people. Legitimacy of DPRD membership recall is regulated in Government Regulation Number 12 of 2018 concerning Guidelines for Arranging Standing Orders of Provincial, Regency and City DPRDs (DPRD Standing Orders). This Government Regulation is the implementing regulation of Law Number 23 of 2014 concerning Regional Government. The legal construction in the regulation of Article 99 paragraph 3 of the DPRD Standing Orders regarding the recall rights of political parties relating to the membership of the DPRD can be terminated between these times with the following reasons:

1. DPRD members do not carry out their obligations on an ongoing or permanent basis as members of the DPRD for 3 (three) months continuously without information;

2. Breaking promises of positions or DPRD code of ethics and oaths;

${ }^{1}$ M. Hadi Shubhan, "Recall": Antara Hak Partai Politik dan Hak Berpolitik Anggota Parpol, Jurnal Konstitusi, Volume 3 Nomor 4, 2006 
3. Has received an incraht verdict pleading guilty;

4. Do not attend the DPRD plenary meeting and / or plenary meeting 6 times continuously;

5. Submitted by his party;

6. Breaking the prohibition as regulated in the legislation

7. No longer fulfilling as a candidate for DPRD member;

8. Dismissed as a member of political parties; or

9. Become a member of another political party.

There are two procedural Recall mechanisms for DPRD membership, namely first the party who submits a political party directly when a political party member dies, receives a criminal sanction of 5 years or more, is dismissed from a political party, and becomes a member of another political party. to the Minister of Home Affairs to formalize the dismissal. The second procedure that submits namely the DPRD, the community to the DPRD Honorary Board to further investigate and verify the results submitted at the DPRD plenary meeting, the decision will then be submitted to the DPRD leadership to be notified to political parties, then can use their rights to recall, but if within 30 days does not decide then the Chairperson of the DPRD will submit it to the Minister of the Interior through the Governor. Article 99 PP of the DPRD regulation stipulates that DPRD members are dishonorably discharged due to reasons as where the letter $b$ (violates the oath / code of ethics), c (gets a criminal sanction), $f$ (no longer meets the candidate requirements, $g$ (violates the provisions of the law). The legal problems with the mechanism of intermission based on the PP are:

First, with regard to the reasons letter b in Article 99 paragraph (3) of this PP the previous mechanism stipulated in Articles 56-60 that can be summarized by the DPRD Honorary Board evaluates the discipline of DPRD membership and investigates and verifies alleged violations of oaths and members of the code of ethics. on the complaint of the leadership or members of the DPRD, and the community. The results of the investigation were submitted to the DPRD plenary meeting, DPRD members who had proven violating the oath provisions or the code of ethics were sentenced to penalties with stages starting from verbal reprimand to dismissal of members. The stages of the imposition of sanctions are not linear with Article 99 paragraph (4) that members of the DPRD who violate one of the letters $\mathrm{b}$ are dishonorably discharged.

Secondly, Article 103 of the DPRD Standing Orders stipulates that the mechanism for intermittent dismissal on the grounds of letter c (obtaining criminal sanctions) is carried out mutatis mutandis, meaning that it is carried out through 1 (one) door namely the proposed political party, but in the PP it does not regulate if based on the reasons c Then the political parties have not proposed it should be submitted by the leadership of the DPRD or the community. Reason letters $\mathrm{f}$ and $\mathrm{g}$ In the PP there is no regulation on the mechanism before the discharge is disrespectfully done, the context no longer meets the requirements of the candidate can be interpreted as the reason for dismissal other than letter reasons $\mathrm{b}$ and $\mathrm{c}$ can be dismissed with no respect. 
Third, Article 102 and Article 105 of the government regulation stipulates that the Minister of Home Affairs formalizes the dismissal of intermittent members of the DPRD, but there is no regulation regarding efforts if the mechanism for intermission of intermission or reasons for termination occur intermittently while the regulation of legal efforts that can be taken is not regulated. PP No. 12 of 2018 also does not regulate the guarantee of returning rights to DPRD members who have been terminated temporarily

This type of research is normative juridical. ${ }^{2}$ This research is used to find the rule of law, legal principles, and legal doctrines in order to address legal issues related to the recll rights of political parties to the membership of the DPRD. Statute approach and conceptual approach were used answering the problems. Primary legal materials are obtained from an inventory of relevant laws and regulations governing the management of village funds, namely primary legal materials: 1. UUD NRI 1945. 2. Law Number 23 of 2014 concerning Regional Government. 3. Government Regulation Number 12 of 2018 concerning Guidelines for Arranging Rules of Procedure for Provincial, Regency, City DPRDs. Secondary legal material, namely the secondary legal material the authors do through literature study related reading literature writing about the recall rights of political parties to the membership of DPRD and literature that supports the collection of concepts and theories that the authors use. The last, Tertiary legal materials are materials that provide instructions and explanations for primary and secondary legal materials in the form of Legal Dictionaries, Local Dictionaries, Black's Law Dictionary, and Large Indonesian Dictionary; Primary legal materials are obtained from the inventory of legislation relevant to political party recall and DPRD membership, while secondary and tertiary legal materials are collected through the UB Library, Legal Studies Documentation Center (PDIH) at the UB Faculty of Law, and visiting the electronic book site.

\section{B. RESULT AND DISCUSSION}

\section{Regulations concerning the Position of Provincial and Regency / City DPRDs}

DPRD functions as a function of supervision, formation of regional regulations and budgets. The difference in Article contained in Article 316 of MD3 Law regulates the function of the Provincial DPRD, namely legislation, budgeting and supervision, which is carried out in the representation of the people in the Province. The revocation of this provision by the Regional Government Law in Article 96 paragraph (1), which is subsequently regulated in Article 2 of the DPRD Standing Orders, stipulates that the function of the Provincial DPRD is the formation of regional regulations, budgets, and supervision. Regional Government has the authority to administer and to regulate regional interests related to government affairs submitted by the Government. Therefore the Regional

\footnotetext{
${ }^{2}$ Peter Mahmud Marzuki, Penelitian Hukum, Jakarta: Kencana Prenada Media Group,2005.
} 
Government has the authority to make Regional Regulations and other necessary regulations. The Draft Regional Regulation may originate from the Regional People's Representative Council or the Regional Head but related to the Regional Regulation and the Regional Budget is the agreement of the Regional People's Representative Council and the Regional Head.

Regional Heads give birth to implementing regulations on regional regulations in the format of Provincial, Regency and City Regional Head Regulations, while Regional People's Legislative Councils carry out oversight of the implementation of regional regulations and APBD. The role of the formation of regional regulations is done by discussing together with the governor and accepting or rejecting the draft of the Provincial Regulation, submitting the proposal of the Provincial Regulation, and compiling a program to form a Regional Regulation with the Governor in the form of a list and priority of the provincial regulations that will be made in 1 (one) budget. The amendment also applies to the provisions of Article governing the position of the Regency / City DPRD.

Effective regional governance can be characterized one of them through regional public policies that are formulated in the Regional Regulation, Regional Budget and Regional Regulation which are determined in accordance with the wishes of the people, and the regional public policies can be implemented, so that the results can be felt by the people. The implementation of regional government will be carried out in accordance with the wishes of the people if the Regional Regulation (Raperda) and APBD Draft are supported (with or without changes) by the majority of DPRD members to become Regional Regulations.

In general, the Draft Regional Regulation and Regional Budget are approved by the DPRD but it is still questionable whether the legal politics in making the regional legal products pay attention to the area of choice in the form of people's wishes or desires. Because in the formulation and discussion of these regulations can not be separated from the scene of political contestation from the authorities or authorities, consequently the regional legal products are in accordance with the wishes of the people or more in line with the interests of the party elites in the DPRD and Executive.

The inclination to make decisions or policies in the DPRD which consists of many political parties with a relatively balanced composition of seats is a form of making a collusive decision, there is no party that is willing to fight for the will of the people themselves with all their strength or body which becomes public policy with the risk of losing ( not get something from the decisions that have been formed) in a decision making. This form of collusive policy making tends to pay more attention to the interests of the bureaucratic elite and party elites than to pay attention to the will of the people.

\section{Legal Implications of Recall Political Party Arrangements on DPRD Membership Based on PP No.12 of 2018}


Recall by political parties to the membership of the DPRD regulated in the DPRD Tatib PP has legal implications namely:

\section{a. Legal Certainty Recall Members of DPRD by Political Parties}

Legal legitimacy for regulating the right to recall political parties contained in Articles 99 through Article 108 PP No. 12 of 2018 provides guarantees and legal certainty to political parties that will conduct direct recall of DPRD members who have committed violations or errors as regulated, namely not carrying out their duties continuously or always unable to become a member of the DPRD for three consecutive months with no information (the DPRD council member is passive in carrying out work or unable to work); Breaking oaths / promises of a DPRD code of ethics; did not come to the meeting of the fittings and / or plenary meetings of the DPRD which have become its obligations and duties for six times continuously without any clear reason; no longer fulfilled the requirements of being a DPRD candidate in accordance with the laws and regulations concerning general elections; or proven to violate the prohibition as regulated in the Act.

A member of a Political Party whose membership has been terminated from a political party is also related to Law No. 2 of 2011 concerning Political Parties. Regarding the procedure for terminating membership of a Political Party as stipulated in paragraph (1) regulated in the Statutes and By-Laws. regarding dismissed members of the Political Party, including members of the people's representative institutions, dismissal from the membership of the Political Party is followed along with dismissal from their membership in the people's representative institutions in accordance with applicable laws and regulations. The issue of dismissal between the times of a DPRD member becomes the business of each political party.

The process still starts from the political party concerned as a candidate for representation, intermittent dismissal there is encouragement from the community and not necessarily immediately. These members can be replaced without going through a process and rules that have been established intermission termination procedures become prerogative rights owned by the party politics, resulting in a member of parliament who is a people's representative who is elected through a democratic procedure that is through elections based on people's power or sovereignty can be dismissed by his party. ${ }^{3}$ With the presence of elected DPRD members is the objective of implementing people's sovereignty, namely as a form of indirectly implementing democracy or representative democracy because of its existence as an institution that sovereigns the people. The existence of a member of parliament, especially members of the Regional House of Representatives who are currently in the people's representative institutions.

3 Jimly Assiddiqie, Partai Politik dan Pemilihan Umum sebagai Instrumen Demokrasi, Jakarta: Mahkamah Konstitusi RI, 2006 


\section{b. Limitation of Political Rights of Members of DPRD}

The right of every citizen to participate in the administration of government which has been explained in Article 28 D paragraph (3) of the 1945 Constitution states that: "Every citizen has the right to have equal opportunities in law and government." The arrangement in this case is a consequence of the recognition that all humans are the same, so no one can be a government without the approval of the governed. Equality in humans results in the regulation of the relationship between humans being established together in the form of legislation, and applied equally to all people, without exception. therefore a democratic country should be a rule of law. All humans have the same position in terms of law and government.

All DPRD members who carry out their duties as DPRD officials are also entitled to have the right to have the same opportunities in law and government as mandated by the constitution, but for legal legitimacy relating to termination of DPRD membership in violation of the provisions of the statutory provisions in this case especially Article 99 The DPRD Standing Orders have legal implications for limiting the right to politics, and carrying out their duties as regional officials.

With the recall right held by political parties to DPRD members, political rights and obligations held as members of the DPRD can be enforced during the term of office, which will then be defeated by the Party Statutes / By-Laws which submit decisionmaking to the Central Management, especially to the Chairperson and to the President of the Political Parties which is a form of the realization of the rights to freedom of association which is closely related to freedom of opinion and freedom of thought and belief. The rights owned are a way for every citizen to participate in government so that the guarantee of those rights is a prerequisite for the creation of a democracy.

The form of society as the holder of all state power is seen during periodic elections which are held according to the principles of democratic elections, freedom and rights of every citizen, political representation system, pluralism party system, as well as political participation of various elements of civil society organizations. ${ }^{4}$ Freedom and loyal rights of citizens will create differences in political views between citizens or between organizations and groups, but the position of each citizen is not only seen as equal before the law, governance by means of a democratic political system will create a democratic culture.

This means that democratic culture in this case is ethics in politics, for example such as mutual respect, "we both have the right to express our own identities and views and therefore we accept and respect the differences between us, but we not only have equal

4 C.F. Strong, Modern Political Constitution, diterjemahkan Derta Sri Widowati, Nusa Media, Bandung, 1966. 
position but also brothers and sisters as fellow countrymen and citizens of the water, "in exercising the right of recall possessed by political parties it should be an act based on law, so that it does not occur simultaneously as well as producing an action that can violate the provisions of the law. Restrictions on political rights implemented by parties related to the people's constitutional rights guaranteed by the constitution are part of violations of the human rights of the people of the country itself.

Recall results in members of the council not getting legal certainty, guarantees, recognition, and protection as well as fair actions related to carrying out their constitutional duties as a member of the DPRD, as protected by the constitution based on Article 28 D (1) and (2) of the 1945 Constitution. also with the Political Party Law Article 12 letter $b$, "dismissed from political party membership for violating the statutes and by-laws", stipulated in Article 99 (3) PP of the DPRD Standing Orders, which says that "members stop intermittently because of proposed political parties concerned ", in fact has allowed private law to override public law related to constitutional issues related to voters, representatives of the people as well as state institutions that obtain their authority from the 1945 Constitution.

Not to erase the planning of political parties in relation to the members of the DPRD related to carrying out constitutional duties, whether it is the function of supervision, the formation of local regulations, and conveying the aspirations of constituents, but in carrying out these roles is not allowed to run without any restrictions identified by placing the legal role the constitution, namely as a public law that participates in regulating it, must see the possibility that the representatives of the people fulfill their oath of office to carry out the duties as fairly as possible, namely by standing up to Pancasila and the 1945 Constitution and also to the applicable laws and regulations, in order upholding democracy in the interests of national and national interests.

The role of political parties, namely as participants in the general election of DPRD members as determined by Article 22E (3) of the 1945 Constitution of the Republic of Indonesia, is clearly justified and legally constitutional, if a member of a political party who is a member of the DPRD declares to withdraw from the membership of his political party that carries it, it is also proposed that he be dismissed as a member of the DPRD. However, if the reason for a political party to propose the withdrawal of its members from the DPRD membership is the reason for violating the Statutes / By-Laws of a Political Party, so it cannot be justified without going through due process of law related to legal procedures that can check the certainty of the reason.

Regional Government is carried out through the principles of decentralization and wide-ranging autonomy to provincial and regional autonomous regions. But political parties are managed centrally. National party management is determined through a National Conference or Conference attended by the Chairperson and Secretary of the 
Party Management at the district and city and provincial levels. But, however, provincial party management has been determined by the Central management. What happens then is not the sovereignty of the party in the hands of its members but the sovereignty in the hands of its management.

Every person who is a candidate for member of Regency or City DPRD and Provincial DPRD, the candidate is determined by the Central Management, and who will be the deputy candidate for the head of the province or district or city must receive recommendations issued by the Central Management. More and more members of the board did not make the party more democratic but instead became more oligarchic. The 1945 Constitution of the Republic of Indonesia as if giving a special place to political parties, does not mean that political parties can negate people's sovereignty as a fundamental principle of the state administration system. The background of this arrangement is due to the New Order period which was inseparable from the role of political parties that had been degraded by the state, namely the sovereignty of the people which shifted to the sovereignty of the state / sovereignty of the state authorities. Therefore, it should not be a shift from the government to political party sovereignty / state sovereignty, but it should be based on people's sovereignty. The consequence of the dismissal of DPRD members by their political parties is that their members are members of parliament on the grounds of violating the Statutes / By-Laws.

\section{c. Termination of Membership Status of Political Parties Implies the Membership Status of DPRD}

The background factor for intermission of intermission intermission is a powerful tool used to attract members of the council that is not in line with the wishes of political parties, on the other hand intermittent dismissal makes it a very powerful tool for attracting members of the board who disagree with the wishes of political party administrators. Resulting in the existence of members of the board is very dependent on the management of political parties, thus shifting the orientation of the members of the council as a liaison to the wishes of political party management. In the event that a constituent of a political party who is dismissed is a member of a representative institution, the dismissal from membership of a Political Party shall be followed by a termination of membership in the DPR or DPRD. the laws and regulations result in ambiguity of interpretation because they do not explain in detail so as to give rise to various interpretations that contain confusion, which can be feared to act arbitrarily to recall members of the DPRD. The termination of political party membership on the proposal of a political party through the recall system has logical consequences as well as termination of membership in the DPRD membership or dismissed intermittently as stipulated in Article 99 paragraph (3) letter h of DPRD Standing Orders that DPRD members can be dismissed intermittently if dismissed by political parties. 


\section{CONCLUSION}

According to the results and discussion of the authors drawn conclusions Legal implications arising from the regulation of political party recall of the membership of the DPRD based on PP No. 12 of 2018 namely restrictions on the political rights of DPRD members, the termination of the status of members of political parties has implications for the termination of the membership of the DPRD, and implications for legal certainty for political parties to recall DPRD members who violate the provisions of Article 99 PP No. 2 of 2018 concerning DPRD Standing Orders which became the legal legitimacy of recalling political parties. It is important for the legislators to be able to conduct an analysis and evaluation of the implementation, especially regulations related to intermittent dismissal of DPRD member.

\section{REFERENCES}

C.F. Strong, Modern Political Constitution, diterjemahkan Derta Sri Widowati, Nusa Media, Bandung, 1966.

Jimly Asshiddiqie, Hukum Tata Negara dan Pilar-Pilar Demokrasi, cetakan kedua, Sinar Grafika, Jakarta, 2012 .

Jimly Assiddiqie, Partai Politik dan Pemilihan Umum sebagai Instrumen Demokrasi, Jakarta: Mahkamah Konstitusi RI, 2006

M. Hadi Shubhan, "Recall": Antara Hak Partai Politik dan Hak Berpolitik Anggota Parpol, Jurnal Konstitusi, Volume 3 Nomor 4, 2006

Peraturan Pemerintah Nomor 12 Tahun 2018 tentang Pedoman Penyusunan Tata Tertib Dewan Perwakilan Rakyat Daerah Provinsi, Kabupaten, dan Kota.

Peter Mahmud Marzuki, Penelitian Hukum, Jakarta: Kencana Prenada Media Group,2005.

Undang-Undang Nomor 23 Tahun 2014 tentang Pemerintahan Daerah Sebagaimana diubah dengan Undang-Undang Nomor 9 Tahun 2015 (Lembaran Negara Nomor 58 Tahun 2015, Tambahan Lembaran Negara Republik Indonesia Nomor 5679) 